\title{
The Potential Impact of Moringa oleifera for Diminishing the Microbial Contamination and Prolonging the Quality and Shelf-Life of Chilled Meat
}

\author{
Mohamed Hamada* (D), Mabrouk Abd Eldaim², Said I. Fathalla ${ }^{3}$, \\ Adil Abalkhail ${ }^{5}$, Ayman El Behiry ${ }^{4,5}$ and Mohamed Alkafafy ${ }^{6}$ (iD \\ ${ }^{1}$ Department of Food Hygiene \& Control, Faculty of Veterinary Medicine, University of Sadat City, Sadat City, Egypt. \\ ${ }^{2}$ Department of Biochemistry and Chemistry of Nutrition, Faculty of Veterinary Medicine, Menoufia University, \\ Shebeen El Kom, Egypt. \\ ${ }^{3}$ Department of Physiology, Faculty of Veterinary Medicine, University of Sadat City, Sadat City, Egypt. \\ ${ }^{4}$ Department of Bacteriology, Mycology and Immunology, Faculty of Veterinary Medicine, University of Sadat, \\ Sadat City, Egypt. \\ ${ }^{5}$ Department of Public Health, College of Public Health and Health Informatics, Qassim University, \\ Al Bukairiyah, Saudi Arabia. \\ ${ }^{6}$ Department of Biotechnology, College of Science, Taif University, P.O. Box 11099, Taif 21944, Saudi Arabia.
}

\begin{abstract}
This study was implemented to assess the mechanism by which Moringa oleifera leaf extract (MOLE) improves the quality and prolongs shelf-life of the broilers' breast meat. Ninety Cobb chicks were randomly allocated to 3 groups. A control group received the standard diet, whereas the other two groups received diets containing MOLE at the doses of 250 and $500 \mathrm{mg} / \mathrm{kg}$ for 21 days. Inclusion of MOLE in broilers diet significantly reduced the detrimental changes in the overall sensory attribute scores, characteristic color and odor, and the loss of breast muscle elasticity during storage. Furthermore, it significantly reduced concentrations of thiobarbituric acid, total volatile nitrogen, non-esterified fatty acids, and peroxide, during storage compared to the control samples. No effect on the concentrations of heavy metals, such as copper, cadmium, and lead, was observed. Decomposition of samples was delayed as indicated by lower $\mathrm{pH}$ values and higher sensory scores at 4 and 6 days of storage in the MOLE groups. Reduced contamination with $E$. coli and Salmonella species indicated an antibacterial effect of MOLE. Finally, the present study highlights that MOLE supplementation may play a role in improving quality and shelf-life of the chilled breast meat in broilers.
\end{abstract}

Keywords: Moringa oleifera, broilers, meat quality, feed additive

*Correspondence: gado722006@gmail.com; +966570993181

(Received: April 27, 2021; accepted: May 16, 2021)

Citation: Hamada M, Eldaim MA, Fathalla SI, Abalkhail A, Behiry AE, Alkafafy M. The Potential Impact of Moringa oleifera for Diminishing the Microbial Contamination and Prolonging the Quality and Shelf-Life of Chilled Meat. J Pure Appl Microbiol. 2021;15(2)826-838. doi: 10.22207/JPAM.15.2.37

(C) The Author(s) 2021. Open Access. This article is distributed under the terms of the Creative Commons Attribution 4.0 International License which permits unrestricted use, sharing, distribution, and reproduction in any medium, provided you give appropriate credit to the original author(s) and the source, provide a link to the Creative Commons license, and indicate if changes were made. 


\section{INTRODUCTION}

There is a constant need for the exploitation of alternate feed additives which promote the development of animals without any negative side effects. Plant extracts comprise various active ingredients that may exert various effects on animals. The active ingredients of phytogenic origin have gained interest due to their wide range of properties. The positive effects of plant extracts on animals, either on health status, productivity, or the quality of the derived products, has been widely studied ${ }^{1,2}$. Plant extracts have been used in poultry production for years. One of the most widely used is that of Moringa oleifera which belonged to the family of Moringaceae ${ }^{3}$. Moringa oleifera is a wonder tree with excellent appetite stimulant effect and abundant nutrients of high nutritive and bioactive value including protein, Vitamin E, Vitamin C, $\beta$-carotene, selenium, zinc, and flavonoids ${ }^{4-6}$. Besides enhancing animal productivity as well as favorably affecting lipid composition, the powerful antioxidants included in $M$. oleifera protect against meat quality deterioration. M. oleifera leaf could be used as an alternative protein source for animal husbandry, as indicated by several studies implemented on a variety of animals, involving cattle, goats, chickens, and fish ${ }^{7}$. In addition, Moringa oleifera has been shown to enhance shelf-life and the overall quality of broiler meat ${ }^{8,9}$. Moreover, Moringa oleifera contains saponins and tannins. Saponins have been reported to bind to cholesterol, to hamper its absorption in the intestine ${ }^{10}$, and subsequently to reduce its accumulation in meat of monogastric animals, while tannins have a positive influence on fatty acids composition of meat ${ }^{11,12}$.

Nowadays, poultry meat quality is of increasing importance, including sensory characteristics, safety, and nutritive value. The main factors that are determined for the assessment of meat quality are juiciness, drip loss, cooking-loss, $\mathrm{pH}$, and shelf-life, since they affect customers' choices and are crucial parameters associated with high quality meat products. In addition, the other important characteristics for the consumers are sensory attributes, like color, tenderness, aroma, and flavor, and nutritional value as they determine meat acceptance ${ }^{8,13}$. Currently, consumers seek high quality meat as assessed by the improved tenderness, low fat, good flavor, good aroma, and juiciness ${ }^{14}$. Another important factor is the safety of meat, which is affected by the extent of microbiological and chemical contamination and controlled by environmental conditions and nutritional supplements. Owing to specific phytochemicals (kaempferitrin, isoquercitrin, rhamnetin, kaempferol and quercetin) and the high content of protein, carotenoids, several minerals, and vitamins; Moringa has been described as a possibly useful feed for animals. It is mainly utilized in chicken nutrition to increase the efficiency of the growth, avoid infections, and enhance appetite by improving meat quality ${ }^{8,15}$. During recent years, considerable interest has been concentrated on utilizing natural antioxidants in food products, due to studies suggesting potential adverse effects that may be related to the consumption of synthetic antioxidants. Natural antioxidants of plant origin are reported to be safe and sound than artificial ones; and did not induce adverse effects on human health ${ }^{16,17}$. Natural compounds are safer and healthier compared to the synthetic antioxidants are increasingly applied in meat systems. They enhance the quality and storage-life of meat and meat-based products when added in animal diets, by decreasing fat and pigment oxidation, which reduces shelf-life and leads to meat quality $\operatorname{loss}^{18-20}$.

Until now, the use of Moringa oleifera in good quality and safe meat production, with no side effects on meat composition, has been limited. Although it was established that $M$. oleifera has significance for the quality and safety of meat production, unluckily, the incorporation of Moringa oleifera in production and preservation of meat is still under consideration. Hence, this research was conducted to investigate the possible ways by which Moringa oleifera leaf extract improves the breast meat quality of broilers and prolongs its stability and shelf-life.

\section{MATERIALS AND METHODS \\ Experimental animals}

This research was performed in accordance with of the animal ethics rules of the Faculty of Veterinary Medicine, University of Sadat City. Research study was carried out in the animal facility of the previously mentioned faculty. Ninety, one-day old, Cobb chicks of both sexes have been obtained from El-Arabia Poultry Company. Water 
and feed were ad libitum provided. Light, naturally, and artificially, was kept 24 hours per day for 2 week, then one hour of darkness was applied daily. Wood shaving was used as bedding material. Strict sanitation practices were applied throughout the experiment. Chicks of all the groups were immunized against infectious bronchitis (IB) strains HIB120 and Newcastle disease (ND) at day 9 of age and against infectious bursal disease (Gumboro) at day 13 of age. There was no vaccination applied during the experimental period (day 14 - 35).

\section{Experimental design}

Chicks were assigned into three groups, 30 birds each, at day 14 of age. The first group received a standard basal diet (Starter 23\% CP $2900 \mathrm{kcal}$, Grower 20\% Crude Protein $3000 \mathrm{kcal}$, and Finisher 18\% CP 31000 kcal $)^{21}$ without any treatment and was used as control group (CON). The second group received a diet mixed with methanolic Moringa oleifera leaf extract (MOLE, $250 \mathrm{mg} / \mathrm{kg}$ feed, MOLE250) from day 14 to day 35 of age. The third group received a diet mixed with MOLE 500mg/kg feed (MOLE500) from day 14 to day 35 of age. All the chicken groups were reared in the same building with identical managing and environmental conditions.

\section{Preparation of Moringa oleifera leaf extract}

Fresh Moringa oleifera (MO) leaves were purchased from a farm at Sadat City, Menoufia governorate, Egypt. For 7 days, fresh $\mathrm{MO}$ leaves were collected and shed dried at room temperature $\left(22^{\circ} \mathrm{C}\right)$ with relative humidity of 65 $\%$. The dry leaves have been ground, filtered, and drenched in $70 \%$ methanol $(50 \mathrm{~g} / \mathrm{L})$. The extract remained for $24 \mathrm{~h}$ with soft shaking at ambient temperature $\left(22^{\circ} \mathrm{C}\right)$. Through Whatman filter paper size No.1, extract was then filtered, and the solvent was evaporated by air current for 24 h. Finally, it was entirely dried out in a hot air oven at $40^{\circ} \mathrm{C}$ for $24 \mathrm{~h}$. The extract was kept in a sealed bottle at $4^{\circ} \mathrm{C}$ until use 22 .

\section{Sample collection}

At the end of the experiment (day 35), chickens were overnightly fasted and euthanized according to the Islamic method of slaughtering. Bleeding of chickens were for $2 \mathrm{~min}$, scalding at $54^{\circ} \mathrm{C}$ for $2 \mathrm{~min}$, defeathering manually, and evisceration. Six animals per group were randomly selected and sampled. Breast was dissected from the left half of the carcasses for further analyses

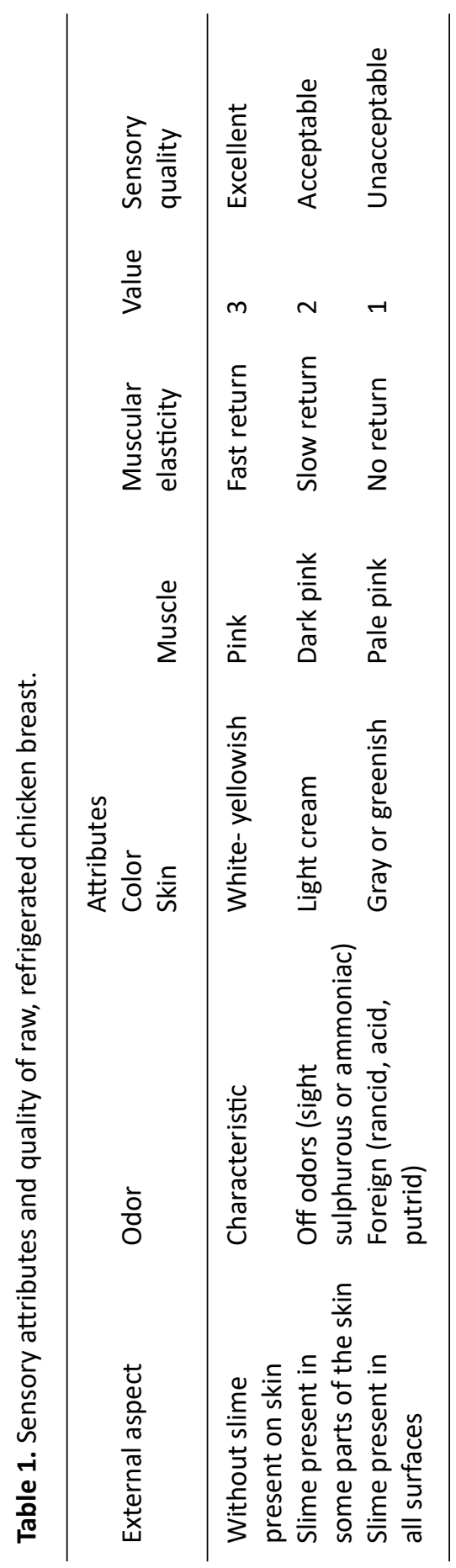


by collecting the part from the caudal ending of the sternum headed for a shoulder joint on either side of every carcass and by dragging the breast aside from the back and shattering the link at the shoulder joints. Each breast sample was divided into four equal parts and kept stored in plastic storage bags at $4^{\circ} \mathrm{C}$ for further analyses at days 0 , 2,4 , and 6 post-mortem.

\section{Determination of sensory parameters}

Meat samples were evaluated at day $0,2,4$, and 6 post-mortem. Sensory attributes and organoleptic characterization of raw meat of broiler breast were determined by a rating scale from 1 to 3 presented in Table $1^{23}$. The examined sensory characteristics were visual appearance (meat and skin color), meat texture, odor, and elasticity. Five qualified judges were trained in the method of tests on raw chicken meat. Also, another five trained judges re-examined the suggested organoleptical method of raw meat assessment. To acquaint the panel with various intensities for the various sensory characteristics of raw chicken meat, and to adapt a scoring scale that should be used, two samplings of $1.5 \mathrm{~h}$ each have been carried out. The sensory profile utilized was received from the previous two sessions opened. Assessments were carried out in a sensual testing room equipped with the positive air pressure, personal stations, and appropriate illumination ${ }^{24}$.

\section{Meat composition}

Crude fiber, protein, fat, water, and ash of broiler breast muscle were determined in accordance with AOAC methods ${ }^{25}$. Moisture has been determined by dry up $1 \mathrm{~g}$ of meat in a furnace at $100-105^{\circ} \mathrm{C}$ till a steady weight has been obtained. Raw protein was determined in accordance with the Kjeldahl method. The raw protein had been obtained as $6.25 \times \mathrm{N} \%$. Lipid content of the meat was determined in accordance with the Soxhlet extraction method utilizing petroleum ether. Ash content of the meat was determined by burning the sample in a muffle furnace at $550^{\circ} \mathrm{C}$ for $3 \mathrm{~h}$. Crude fiber was determined in accordance with boiling sample with $1.25 \%$ diluted $\mathrm{H}_{2} \mathrm{SO}_{4}$, rinsed with water, further boiled with $1.25 \%$ diluted sodium hydroxide and the residual deposit after the digestive process had been taken as crude fiber.

\section{Determination of meat quality}

\section{Determination of $\mathrm{pH}$ of the breast muscle}

Determination of $\mathrm{pH}$ values was performed using a pH Measuring Device (Germany, Testo 205) by penetrating breast muscle.

\section{Determination of Total Volatile Nitrogen (TVN) of} the breast muscle

The TVN of the breast muscle was determined according to Conway and Byrne ${ }^{26}$. In a clean dry beaker, $10 \mathrm{~g}$ of the sample were added to $30 \mathrm{ml}$ of distilled water and thoroughly mixed by a blender for $2 \mathrm{~min}$. Thus, 2 drops of $0.02 \mathrm{M}$ $\mathrm{HCl}$ were added to bring the $\mathrm{pH}$ value to 5.2. The homogenate was slowly heated to $70^{\circ} \mathrm{C}$ and then cooled to room temperature and filtered into the inner compartment of Conway dish and then $2 \mathrm{ml}$ of $0.01 \mathrm{M} \mathrm{HC} 1$ were added. The outer ring was filled with $2 \mathrm{ml}$ of the sample extract and $1 \mathrm{ml}$ of saturated potassium carbonate (KCO3). The Conway unit was rotated as gently as possible and the dish was covered and incubated at $36^{\circ} \mathrm{C}$ for two hours, $\mathrm{HCl}$ in the inner ring was titrated against $0.01 \mathrm{M} \mathrm{NaOH}$ by using methyl red indicator $\left(\mathrm{T}_{1} \mathrm{ml}\right)$. $\mathrm{TVN} / \mathrm{I00 \textrm {g }}=26.88 \times\left(2-\mathrm{T}_{1}\right)$, Where $\mathrm{T}_{1}=$ volume of $\mathrm{NaOH}$ expended in the titration.

\section{Determination of Thiobarbituric Acid Number} $(\text { TBA })^{27}$

TBA test is based on determination of malonaldehyde (MDA) values as a product of lipid peroxidation. The degree of oxidative rancidity is usually stated as TBA number and stated as milligrams of malonaldehyde counterparts per kilogram of samples. A sample of ten grams was mixed with $50 \mathrm{ml}$ of distilled water in warring blender for $2 \mathrm{~min}$. The mix was quantitatively transported into Kjeldahl flask by wash with an extra $47.5 \mathrm{ml}$ of distilled water. Though, $2.5 \mathrm{ml}$ of $\mathrm{HCL}$ were added to $125 \mathrm{ug} / \mathrm{g}$ fat and then a small number of stones was sited to stop pumping. The flask was heated at the maximum heat reachable in the Kjeldahl distillation device. Approximately, $10 \mathrm{~min}$ after the boiling were essential to gather $50 \mathrm{ml}$ of the concentrate. Therefore, $5 \mathrm{ml}$ of the concentrate were mixed to $5 \mathrm{ml}$ of TBA reagent in $50 \mathrm{ml}$ glass stoppered tube. The contents were immersed and mixed in a boiling water bath for $35 \mathrm{~min}$. Like samples, a distilled water TBA reagent blank was intended and handled. After boiling, cooling under tape water for 10 min was 
applied. The sample optical density alongside the reference liquid (blank) was measured by using Spectrophotometer (UNICAM969AA Spectronic, USA) at a wavelength of $538 \mathrm{~nm}$. Concentration of malonaldehyde $(\mathrm{mg} / \mathrm{kg})=\mathrm{Rx} 7.8$, Where $\mathrm{R}=$ the absorbance.

\section{Determination of Peroxide Value (PV)}

The peroxide value has been determined according to Asakawa et al. ${ }^{28}$. The titre of the sodium thiosulfate solution was determined, where the precise normality of $\mathrm{Na}_{2} \mathrm{~S}_{2} \mathrm{O}_{3}$ realizing that in this chemical reaction 1gram-equivalent of $\mathrm{Na}_{2} \mathrm{~S}_{2} \mathrm{O}_{3}$ react with 1 gram-equivalent of $\mathrm{K}_{2} \mathrm{Cr}_{2} \mathrm{O}_{7}$ (6moles $\mathrm{Na} 2 \mathrm{~S} 2 \mathrm{O} 3$ react with 1 mole $\mathrm{K}_{2} \mathrm{Cr}_{2} \mathrm{O}_{7}$ ) was determined. Peroxide value determination by titration with sodium thiosulfate until blue colour disappeared. The titration procedure was repeated as a minimum 3 times and the single findings should not differ greater than $0.3 \mathrm{ml}$. For all samples, PV was evaluated by the formula: PV $=\left(V_{1}-V_{0}\right) \times T \times 1000 / \mathrm{m}$ (ml equivalent available oxygen $/ \mathrm{kg}$ ). Where, $\mathrm{V}_{1}=$ volume of thiosulfate solution needed to titrate the sample $(\mathrm{ml}), \mathrm{V}_{0}=$ volume of thiosulfate solution essential to titrate the blank, $\mathrm{T}=$ sodium thiosulfate solution titre (normality) and $\mathrm{m}=$ sample weight (g).

\section{Determination of Free Fatty Acids (FFA)}

Lipid was extracted by using 1 part of the inspected sample to the original extract ratio of 20 parts of $2: 1$ dichloromethane/methanol ${ }^{29}$. A final ratio of 8:4:3 dichloromethane/ methanol/ water was achieved, by adding a weak salt solution $(0.66 \% \mathrm{NaCl})$, containing the water included inside the tissue. Titration procedure ${ }^{30}$ was modified to the sample nature and quantity. The sample fat extract was vaporized with nitrogen and dissolved in previously neutralized ethanol with cresol purple and $60^{\circ} \mathrm{C}$ preheated. Three repeats of sample were used titrated with $\mathrm{N} \mathrm{NaOH}$ to a violet end point Cresol purple has been planned to enhance the sensitivity of the technique and has been used to a titration of lipid fish extracts ${ }^{31}$. In this case, $0.05 \mathrm{~N} \mathrm{NaOH}$ had been used for the titration of an extract to a violet end point cresol purple. Consequently, FFA values were registered as a proportion of oleic acid which equivalent $(\mathrm{ml}$ $\mathrm{NaOH} X \mathrm{NaOH}$ normality $X 28.2$ ) / sample weight. Determination of heavy metals

The standard, blank and digest solutions were aspirated by Atomic Absorption Spectrometer
(AAS, VARIAN, Australia, model AA240 FS) and analyzed for content of heavy metal. Investigation was carried out by air/acetylene flow (5.5/1.11/m) flame for $\mathrm{Cd}, \mathrm{Cu}$ and $\mathrm{Pb}$ concentrations $(\mathrm{mg} / \mathrm{kg}$ wet weight $)^{25}$. Detection limit (ppb) 8-40 for $\mathrm{Pb}$, 0.2-0.8 for $\mathrm{Cd}$ and 11-25 for $\mathrm{Cu}$. The three heavy metal levels were verified from the digital scale of AAS and intended rendering to the equation: Metal concentration (ppm) $\mathrm{C}=\mathrm{Rx}(\mathrm{D} / \mathrm{W})$, where $\mathrm{C}=$ heavy metal concentration (wet weight), $\mathrm{R}=$ digital scale reading of AAS, $D=$ prepared sample dilution and $W=$ sample weight. Each heavy metal concentration in the blank solution was also determined and subtracted from each examined sample ${ }^{32}$.

\section{Bacteriological examination}

Samples were prepared for bacteriological examination according to ICMSF $^{33}$. In brief, $225 \mathrm{ml}$ of sterile peptone water were added to $25 \mathrm{~g}$ of the sample, and completely blended utilizing sterile stomacher for 1-1.5 min.

\section{Bacterial screening}

\section{E. coli screening}

Immediately after slaughter, samples were screened for $E$. coli according to $\mathrm{ISO}^{34}$. Concisely, 1 milliliter from the initial dilution, was injected into MacConkey broth tubes supplemented by inverted Durham's tubes. The injected tubes remained at $37^{\circ} \mathrm{C}$ for 24 hours. From positive MacConkey tube, 1 milliliter was injected into one more MacConkey broth tube and developed at $44^{\circ} \mathrm{C}$ for 24 hours. Loopfuls from the positive MacConkey broth tubes, were individually streaked onto Eosin Methylene Blue agar medium $(E M B)$, which was then developed at $37^{\circ} \mathrm{C}$ for 24 hours. The presumed colonies were seemed like metallic green in color. Into slope nutrient agar tubes, the presumed colonies were then inoculated and purified for further recognition.

\section{Salmonella screening}

Salmonella screening was carried out according to the method described by Harvey and Price $^{35}$. In brief, one milliliter of the initial dilution was injected into nine milliliter Rappaport Vassilidis broth tube, and then the tube was stored at $43^{\circ} \mathrm{C}$ for 24 hours. On Xylose lysine desoxychoclate (XLD) agar medium, loopfuls from the inoculated tubes were individually streaked and developed at $37^{\circ} \mathrm{C}$ for 24 hours. The presumed colonies were looked as red with or without black centers. On nutrient 
agar plates, the presumed colonies were then reared and sub-cultivated at $37^{\circ} \mathrm{C}$ for 24 hours. On slope nutrient agar, the purified suspected colonies were selected and streaked for further recognition.

\section{Staphylococcus aureus screening}

Staphylococcus aureus screening was performed according to ICMSF $^{33}$. On duplicated plates of Baired Parker agar (BPA) and using a sterile glass spreader, $0.1 \mathrm{ml}$ from formerly ready dilution was spread. At $37^{\circ} \mathrm{C}$ for 48 hours, the injected and control plates were incubated. On nutrient agar slopes, the black colonies surrounded with clear zone have been chosen up and purified for further proof of identity.

Morphological, biochemical, and serological identification

According to Cruickshank et al. ${ }^{36}$, morphological examination has been conducted, while biochemical identification of $E$. coli was conducted according to the Krieg and Holt ${ }^{37}$. According to Kok et al. ${ }^{38}$, isolates were serologically recognized by using rapid diagnostic $E$. coli antisera sets (DENKA SEIKEN Co., Japan). The presumptive colonies of Salmonella were further subjected to biochemical tests; indole, methyl red, VogesProskauer and Citrate test (IMViC) as per the standard test protocol described in Bacteriological Analytical Manual FDA ${ }^{39}$. Salmonellae were serologically identified according to KauffmanWhite scheme ${ }^{40}$ for the determination of flagellar $(\mathrm{H})$ and Somatic (O) antigens using Salmonella antiserum (DENKA SEIKEN Co., Japan). Staphylococcus aureus was tested for production of catalase, free coagulase, yellow pigment, and thermonuclease (TNase) according to Lancette et al. ${ }^{41}$.

\section{Statistical analysis}

Data obtained in this research were analyzed by using SAS statistical software (Version 9.3, SAS Inst., Cary, USA), data obtained in this research were investigated. Heavy metal concentration and meat composition data were analyzed with simple ANOVA and Tukey's posthoc test. Quality traits and Sensory data were analyzed by ANOVA using the MIXED procedure with fixed factor group and repeated factor storage day (with autoregressive covariance structure) and group $x$ storage day interaction. The TukeyKramer correction was used to manage the Family-wise Error Rate (referred to as Padj). The results are presented as LSmean \pm standard error (SE). Differences were deemed to be significant if Padj $\leq 0.05$.

\section{RESULTS}

\section{Composition of broiler breast muscle}

Feeding of broilers on diets containing MOLE at concentrations of 250 or $500 \mathrm{mg} / \mathrm{kg}$ of diet (groups MOLE250 and MOLE500, respectively) did not have any significant impact $(P>0.05)$ on composition of meat as shown in Table 2. Similar values were obtained in all three groups for ash, protein, fat, crude fiber, and water concentrations of the breast muscle.

\section{Sensory characteristics during storage}

The sensory quality of broiler breast muscle declined during storage in all three groups as indicated in Table 3, as expected. Meat of the CON group became unacceptable for human consumption already after day 2 of storage. This was obvious in all individual sensory characteristics and overall scores. Addition of MOLE in broiler diet delayed the sensory changes of the breast muscles over the storage period until unacceptability as in Table 3. External aspect differed between CON and MOLE500 samples already at day 0. External aspect, muscular elasticity, and overall score were different between CON and MOLE500 at day 2 of storage. Color and odor were not different between CON and both MOLE groups. However, the overall score was higher $(P<0.05)$ in both MOLE group samples at days 2 and 4 of storage and was highest $(P<0.05)$ in the MOLE500 group samples at day 6 . The positive effect of MOLE on sensory quality of broiler meat was slightly stronger with higher MOLE concentration in the diet.

\section{Objective quality parameters}

Storage of the breast muscles at $4{ }^{\circ} \mathrm{C}$ increased $(\mathrm{P}<0.001)$ meat $\mathrm{pH}$ and the concentrations of TVN, TBA, peroxide, and NEFA as shown in Table 4. Inclusion of MOLE in the diet of broiler chicks at concentrations 250 and $500 \mathrm{mg} / \mathrm{kg}$ of diet significantly delayed detrimental changes. Compared to $\mathrm{CON}$, the $\mathrm{pH}$ was decreased $(P<0.05)$ from fourth day of storage through the MOLE group samples. The concentrations of TVN, TBA, peroxide, and NEFA were lower $(P<0.05)$ in MOLE500 samples and in most cases also in MOLE250 samples from day 2 of storage. Differences between both MOLE groups were 
observed at day 6 of storage in TBA and peroxide concentrations indicating dose dependency of the beneficial effects.

\section{Concentrations of heavy metals}

Cadmium and lead were detected in about $50 \%$ of the investigated samples of all groups, whereas copper was measurable in all specimens. The concentration of heavy metals into individual specimens was highly variable.
The analysis of variance revealed no significant influence $(P>0.05)$ of supplementation with MOLE, irrespective of the amount applied, on the concentrations of heavy metals in broiler breast muscle as in Table 5.

\section{Bacterial contamination}

Four out of 6 samples of the CON group were contaminated with potentially pathogenic bacteria. One sample was tested positive for

Table 2. Effect of Moringa oleifera leaf extract (MOLE) on breast muscle composition

\begin{tabular}{lcccc}
\hline Trait & \multicolumn{3}{c}{ Group } \\
MOLE250 & MOLE500 & P-value \\
\hline Ash (\%) & $1.63 \pm 0.08$ & $1.58 \pm 0.09$ & $1.53 \pm 0.09$ & 0.735 \\
Fat (\%) & $3.17 \pm 0.13$ & $3.10 \pm 0.12$ & $2.98 \pm 0.14$ & 0.599 \\
Protein (\%) & $19.7 \pm 0.21$ & $20.0 \pm 0.22$ & $20.3 \pm 0.25$ & 0.181 \\
Crude fiber (\%) & $1.00 \pm 0.09$ & $0.88 \pm 0.08$ & $0.82 \pm 0.09$ & 0.354 \\
Moisture (\%) & $73.5 \pm 0.31$ & $73.3 \pm 0.30$ & $73.2 \pm 0.28$ & 0.817 \\
\hline
\end{tabular}

Data are expressed as LSmeans \pm SE; CON - control group, MOLE250 - group supplemented with 250 mg MOLE / kg diet, MOLE500 - group supplemented with $500 \mathrm{mg}$ MOLE / kg diet.

Table 3. Effect of Moringa oleifera leaf extract (MOLE) on sensory characteristics of breast muscle

\begin{tabular}{|c|c|c|c|c|c|c|c|c|}
\hline Trait & $\begin{array}{c}\text { Storage } \\
\text { day }\end{array}$ & CON & $\begin{array}{c}\text { Group } \\
\text { MOLE250 }\end{array}$ & MOLE500 & SE & Group & $\begin{array}{c}\text { P-value } \\
\text { Storage } \\
\text { day }\end{array}$ & $\begin{array}{c}\text { Group } \\
\text { Storage } \\
\text { day }\end{array}$ \\
\hline \multirow{4}{*}{$\begin{array}{l}\text { External } \\
\text { aspect }\end{array}$} & 0 & $2.0^{\mathrm{a}, \mathrm{A}}$ & $2.3^{\mathrm{a}, \mathrm{A}}$ & $2.8^{\mathrm{a}, \mathrm{B}}$ & 0.16 & $<0.001$ & $<0.001$ & $<0.001$ \\
\hline & 2 & $1.0^{\mathrm{b}, \mathrm{A}}$ & $1.0^{\mathrm{b}, \mathrm{A}}$ & $2.7^{\mathrm{a}, \mathrm{B}}$ & & & & \\
\hline & 4 & $1.0^{\mathrm{b}, \mathrm{A}}$ & $1.3^{\mathrm{b}, \mathrm{A}}$ & $2.2^{\mathrm{ab}, \mathrm{B}}$ & & & & \\
\hline & 6 & $1.0^{\mathrm{b}}$ & $1.0^{\mathrm{b}}$ & $1.5^{\mathrm{b}}$ & & & & \\
\hline \multirow[t]{4}{*}{ Odor } & 0 & $1.7^{\mathrm{a}}$ & $1.8^{\mathrm{a}}$ & $1.7^{\mathrm{a}}$ & 0.13 & 0.554 & $<0.001$ & 0.340 \\
\hline & 2 & $1.0^{\mathrm{b}}$ & $1.0^{\mathrm{b}}$ & $1.3^{\mathrm{ab}}$ & & & & \\
\hline & 4 & $1.0^{\mathrm{b}}$ & $1.0^{\mathrm{b}}$ & $1.2^{\mathrm{ab}}$ & & & & \\
\hline & 6 & $1.0^{\mathrm{b}}$ & $1.0^{\mathrm{b}}$ & $1.0^{\mathrm{b}}$ & & & & \\
\hline \multirow[t]{4}{*}{ Color } & 0 & $2.2^{\mathrm{a}}$ & $2.3^{\mathrm{a}}$ & $2.3^{\mathrm{a}}$ & 0.15 & 0.369 & $<0.001$ & 0.463 \\
\hline & 2 & $1.2^{\mathrm{b}}$ & $1.2^{\mathrm{b}}$ & $1.5^{\mathrm{b}}$ & & & & \\
\hline & 4 & $1.0^{\mathrm{b}}$ & $1.0^{\mathrm{b}}$ & $1.3^{\mathrm{b}}$ & & & & \\
\hline & 6 & $1.0^{\mathrm{b}}$ & $1.0^{\mathrm{b}}$ & $1.0^{\mathrm{b}}$ & & & & \\
\hline Muscular & 0 & $2.3^{\mathrm{a}}$ & $2.3^{\mathrm{a}}$ & $2.8^{\mathrm{a}}$ & 0.18 & 0.002 & $<0.001$ & 0.008 \\
\hline \multirow[t]{3}{*}{ elasticity } & 2 & $1.3^{\mathrm{b}, \mathrm{A}}$ & $1.3^{\mathrm{b}, \mathrm{A}}$ & $2.5^{\mathrm{a}, \mathrm{B}}$ & & & & \\
\hline & 4 & $1.0^{\mathrm{b}}$ & $1.5^{\mathrm{b}}$ & $1.7^{\mathrm{b}}$ & & & & \\
\hline & 6 & $1.0^{\mathrm{b}}$ & $1.0^{\mathrm{b}}$ & $1.2^{\mathrm{b}}$ & & & & \\
\hline Overall & 0 & $8.2^{\mathrm{a}}$ & $8.8^{\mathrm{a}}$ & $9.7^{a}$ & 0.42 & $<0.001$ & $<0.001$ & $<0.001$ \\
\hline \multirow[t]{3}{*}{ score } & 2 & $4.2^{\mathrm{b}, \mathrm{A}}$ & $6.8^{\mathrm{b}, \mathrm{B}}$ & $8.0^{\mathrm{b}, \mathrm{B}}$ & & & & \\
\hline & 4 & $1.3^{\mathrm{c}, \mathrm{A}}$ & $4.7^{\mathrm{c}, \mathrm{B}}$ & $6.3^{\mathrm{c}, \mathrm{B}}$ & & & & \\
\hline & 6 & $1.0^{\mathrm{c}, \mathrm{A}}$ & $1.8^{\mathrm{d}, \mathrm{AB}}$ & $3.8^{\mathrm{d}, \mathrm{B}}$ & & & & \\
\hline
\end{tabular}

Data are expressed as LSmeans \pm SE; CON - control group, MOLE250 - group supplemented with 250 mg MOLE / kg diet, MOLE500 - group supplemented with $500 \mathrm{mg}$ MOLE / kg diet.

${ }^{a-d}$ different lowercase superscript letters indicate significant differences among storage days within a group $(P<0.05)$

$A, B$ different capital superscript letters indicate significant differences among groups within a storage day $(P<0.05)$ 
Salmonella Kentuckey, one for Salmonella Enteritidis, and another for E. coli 078. The sample positively tested for $E$. coli $\mathrm{O} 1: \mathrm{H} 7$ was additionally contaminated with $S$. aureus. Meat of MOLE supplemented broilers had less bacterial contaminations. Three out of 6 MOLE250 and 1 out of 6 MOLE500 samples were tested positive for bacteria. One MOLE250 sample was positive for Salmonella Kentuckey and E. coli O78, one for Staphylococcus aureus, and another for $E$. coli O78. Moreover, the positively tested meat sample of the MOLE500 group was contaminated with Salmonella Kentuckey only.

Table 4. Effect of Moringa oleifera leaf extract (MOLE) on objective meat quality traits of breast muscle

\begin{tabular}{|c|c|c|c|c|c|c|}
\hline Trait & $\begin{array}{c}\text { Storage } \\
\text { day }\end{array}$ & CON & $\begin{array}{c}\text { Group } \\
\text { MOLE250 }\end{array}$ & MOLE500 & SE & $\begin{array}{c}\text { P-value } \\
\text { Group } \\
\text { Storage } \\
\text { day }\end{array}$ \\
\hline \multirow[t]{4}{*}{$\mathrm{pH}$} & 0 & $5.78^{a}$ & $5.71^{\mathrm{a}}$ & $5.66^{a}$ & 0.14 & $<0.0001$ \\
\hline & 2 & $6.09^{b}$ & $5.86^{a}$ & $5.84^{a}$ & & \\
\hline & 4 & $8.13^{\mathrm{c}, \mathrm{A}}$ & $6.33^{b, B}$ & $6.17^{\mathrm{b}, \mathrm{B}}$ & & \\
\hline & 6 & $8.70^{\mathrm{d}, \mathrm{A}}$ & $7.54^{\mathrm{c}, \mathrm{B}}$ & $7.24^{\mathrm{c}, \mathrm{B}}$ & & \\
\hline \multirow[t]{4}{*}{ TVN } & 0 & $7.65^{a}$ & $6.24^{\mathrm{a}}$ & $5.74^{\mathrm{a}}$ & 2.14 & $<0.0001$ \\
\hline & 2 & $20.95^{b, A}$ & $15.61^{b, A B}$ & $8.16^{a, b}$ & & \\
\hline & 4 & $37.38^{\mathrm{c}, \mathrm{A}}$ & $22.87^{\mathrm{c}, \mathrm{B}}$ & $17.31^{b, B}$ & & \\
\hline & 6 & $52.80^{d, A}$ & $38.28^{d, B}$ & $31.38^{c, B}$ & & \\
\hline \multirow[t]{4}{*}{ TBA } & 0 & $0.11^{\mathrm{a}}$ & $0.08^{a}$ & $0.07^{a}$ & 0.09 & $<0.0001$ \\
\hline & 2 & $0.99^{b, A}$ & $0.53^{b, B}$ & $0.37^{\mathrm{b}, \mathrm{B}}$ & & \\
\hline & 4 & $1.36^{\mathrm{c}, \mathrm{A}}$ & $0.90^{\mathrm{c}, \mathrm{B}}$ & $0.68^{c, B}$ & & \\
\hline & 6 & $1.77^{\mathrm{d}, \mathrm{A}}$ & $1.46^{\mathrm{d}, \mathrm{A}}$ & $0.99^{\mathrm{d}, \mathrm{B}}$ & & \\
\hline \multirow[t]{4}{*}{ Peroxide } & 0 & $0.24^{\mathrm{a}}$ & $0.16^{a}$ & $0.12^{\mathrm{a}}$ & 0.11 & $<0.0001$ \\
\hline & 2 & $1.83^{\mathrm{b}, \mathrm{A}}$ & $0.89^{b, B}$ & $0.67^{b, B}$ & & \\
\hline & 4 & $2.87^{\mathrm{c}, \mathrm{A}}$ & $1.54^{\mathrm{c}, \mathrm{B}}$ & $1.14^{\mathrm{c}, \mathrm{B}}$ & & \\
\hline & 6 & $3.26^{\mathrm{d}, \mathrm{A}}$ & $2.05^{\mathrm{d}, \mathrm{A}}$ & $1.71^{\mathrm{d}, \mathrm{B}}$ & & \\
\hline \multirow[t]{4}{*}{ FFA } & 0 & $0.16^{\mathrm{a}}$ & $0.09^{a}$ & $0.06^{a}$ & 0.05 & $<0.0001$ \\
\hline & 2 & $0.70^{\mathrm{b}, \mathrm{A}}$ & $0.28^{\mathrm{b}, \mathrm{B}}$ & $0.22^{\mathrm{b}, \mathrm{B}}$ & & \\
\hline & 4 & $1.04^{\mathrm{c}, \mathrm{A}}$ & $0.47^{\mathrm{c}, \mathrm{B}}$ & $0.33^{b, B}$ & & \\
\hline & 6 & $1.40^{\mathrm{d}, \mathrm{A}}$ & $0.66^{\mathrm{d}, \mathrm{B}}$ & $0.56^{\mathrm{c}, \mathrm{B}}$ & & \\
\hline
\end{tabular}

Data are expressed as LSmeans \pm SE; CON - control group, MOLE250 - group supplemented with 250 mg MOLE / kg diet, MOLE500 - group supplemented with $500 \mathrm{mg}$ MOLE / kg diet.

a-d different lowercase superscript letters indicate significant differences between storage days within a group $(P<0.05)$

$A, B$ different capital superscript letters indicate significant differences between groups within a storage day $(P<0.05)$

$\mathrm{pH}$ (acidity), TVN (total volatile nitrogen, $\mathrm{mg} / 100 \mathrm{~g}$ ), TBA (thiobarbituric acid, $\mathrm{mg} / \mathrm{kg}$ ), FFA (free fatty acids, $\mathrm{mg} \mathrm{KOH} / \mathrm{g}$ ), Peroxide (meq)

Table 5. Effect of Moringa oelifera leaf extract (MOLE) on concentrations of heavy metals in breast muscle

\begin{tabular}{lcccc}
\hline Heavy metal & CON & $\begin{array}{c}\text { Group } \\
\text { MOLE250 }\end{array}$ & MOLE500 & P-value \\
\hline Cadmium $(\mathrm{mg} / \mathrm{kg})$ & $0.20 \pm 0.14$ & $0.16 \pm 0.10$ & $0.16 \pm 0.09$ & 0.949 \\
Copper $(\mathrm{mg} / \mathrm{kg})$ & $1.06 \pm 0.25$ & $0.84 \pm 0.23$ & $0.74 \pm 0.21$ & 0.625 \\
Lead $(\mathrm{mg} / \mathrm{kg})$ & $0.55 \pm 0.29$ & $0.25 \pm 0.17$ & $0.19 \pm 0.14$ & 0.464 \\
\hline
\end{tabular}

Data are expressed as LSmeans \pm SE; CON - control group, MOLE250 - group supplemented with 250 mg MOLE / kg diet, MOLE500 - group supplemented with $500 \mathrm{mg}$ MOLE / kg diet. 


\section{DISCUSSION}

With the intention to produce valueadded meat and to determine its acceptance, consumers and processor consider several meat quality traits, including sensory characteristics, quality parameters, nutritious value, and health effects $^{42,43}$. Firstly, the visual aspect quality traits (external aspect, color, and odor) and the muscular elasticity are regarded as the key characteristics that determine consumers' initial preference for meat ${ }^{43}$. Feed additives are used to improve performance of broilers, and at the same time meat quality and shelf-life. Moringa oleifera leaves are used as feed additive and due to their high nutritive value improve feed intake and digestibility and lead to enhanced performance in monogastric animals ${ }^{15}$. Moringa oleifera has been described to enhance the storage-life as well as the quality of broiler meat ${ }^{8,44}$. We used two concentrations of MOLE in the current study as feed additive and investigated the effects on meat quality and shelflife of broiler breast muscle. Meat composition was not influenced by MOLE supplementation. However, the findings of our research indicated that the breast muscle sensory attributes of broilers fed a standard diet without MOLE (control group) became earlier unacceptable upon storage under chilling condition. The inclusion of MOLE in broilers diet delayed the unacceptable changes in the sensory quality of the breast muscles over the period of storage ( 6 days). Thus, it can be concluded that MOLE improves the shelf-life of broiler meat, as reflected in part of the sensory parameters (overall scores, external aspect, and muscle elasticity), under chilling condition. These findings were consistent with that of Cui et al 45, who concluded that Moringa oleifera can be used as feed ingredient for broilers to improve meat quality and consistent with Karthivashan et al. ${ }^{46}$, who stated that feeding of broilers on diet supplemented with MOLE, $0.5 \% \mathrm{w} / \mathrm{w}$, improved its meat quality. In another study ${ }^{8}$, MOLE as feed additive affected the color of broiler breast meat as well as the color stability over time until day 6. The effects were pronounced with the highest level of MOLE (1000g/ton diet). On the other hand, Qwele et al. ${ }^{21}$ observed no effect of dietary supplementation of Moringa (5:20\% of the diet) formulated diets on broilers meat color.
The improvement of meat quality in broilers fed diets containing MOLE may be attributed to the anti-oxidative potential of MOLE ${ }^{47}$. Meat quality attributes as ultimate $\mathrm{pH}$, TVN, TBA, peroxide and NEFA and shelf-life are key parameters taken into consideration in the evaluation of meat by the consumer as well as the processor. Meat quality has been affected, to a great extent, by the percentage of ultimate $\mathrm{pH}$, and its drop in the muscles after slaughter ${ }^{42,43}$. The $\mathrm{pH}$ was not different among the groups in our study until day 2 of storage. However, the $\mathrm{pH}$ increased thereafter much faster in CON than MOLE samples indicating decay initiation. Storage of breast muscles of the CON group under chilling condition deteriorated values of quality parameters $(\mathrm{pH}$ and TVN, TBA, peroxide and NEFA) induced by conversion and dismounting of lipids and proteins of the meat. Inclusion of MOLE in broiler diets improved the quality showing a reduced increase in values of $\mathrm{pH}, \mathrm{TVN}$, TBA, peroxide and NEFA and increasing shelf-life compared to meat of the CON group. These results were in accordance with that of Wapi et al. ${ }^{8}$ who mentioned that MOLE as an additive affects the $\mathrm{pH}$ of broiler breast meat as well as its stability over time until day 6 . The effects were pronounced with the highest level of MOLE (1000g/ton MOLE). In contrast, dietary supplementation of broilers with Moringa formulated diets had no effect on the meat $\mathrm{pH}$ in the study of Qwele et al. ${ }^{21}$. Type of extract and used concentrations may be responsible for the observed discrepancies. The results of our study support conclusions that intake of feed supplemented with MOLE could be useful to improve the meat quality for human consumption. It was reported that MOLE is abundant in antioxidant compounds, such as terpenoids, coumarin, flavonoids, triterpenoids, sterols, saponins, alkaloids, and phenolics ${ }^{48-50}$. Antioxidant function of MOLE reduces the intensity of malondialdehyde (MDA) and fat peroxidative products ${ }^{51,52}$. Moreover, it increases the intensity of glutathione (GSH) as well as the activities of antioxidant enzymes superoxide dismutase and catalase $\mathrm{e}^{52-55}$, because it is also rich in further antioxidant compounds such as vitamin c, selenium, oleic acid, phenolic compounds, and carotenoids. M. oleifera might also become 
a perfect candidate as a food preservative by inhibiting proteolysis via its protease inhibitor, in food industry ${ }^{56}$.

The other possible cause for improving the meat quality and prolonging its shelf-life is the reducing potential of MOLE through its low content of heavy metals, such as copper (Cu), cadmium ( $\mathrm{Cd}$ ), and lead ( $\mathrm{Pb}$ ). Heavy metals induce reactive oxygen species (ROS) generation and cause lipid peroxidation, membrane dismantling and damage to DNA, protein, and carbohydrates ${ }^{57}$. Our study revealed no difference in the heavy metal's concentration of $\mathrm{Cd}, \mathrm{Cu}$, and $\mathrm{Pb}$ in broilers breast muscle compared to the control. Heavy metals such as cadmium which are possibly toxic are missing from Moringa oleifera leaves, thereby making their inclusion safe in poultry diets ${ }^{58}$. Thus, a daily intake of considerable amounts of toxic heavy metals $\mathrm{Pb}, \mathrm{Cd}$, and $\mathrm{Cu}$, resulting in poor quality of poultry meat ${ }^{59}$, is prevented. Cd, $\mathrm{Cu}$, and $\mathrm{Pb}$, are problematic for humans through ingestion by food in our daily diet ${ }^{59}$. Monitoring of heavy metals in poultry meat and meat products is therefore important for providing good quality poultry meat products for human consumption. Poultry meat which exceeds the maximum permissible limits of heavy metals may be declared as unsuitable for human consumption ${ }^{59}$.

Another positive aspect of feeding broiler with diets containing MOLE, especially $500 \mathrm{mg}$ / $\mathrm{kg}$ diet, is the reduced bacterial contamination of their meat. The anti-bacterial activity of MOLE against different species of bacteria such as: E. coli, S. aureus and S. typhi has been highlighted by many authors. It was attributed to flavonoids, tannins, steroid, alkaloid, saponins contained in MOLE which have anti-bacterial properties ${ }^{60}$. Moringa oleifera leaf meal could serve as alternative to antibiotics in broiler production as this is in attempt to reduce antimicrobial resistance ${ }^{61}$.

\section{CONCLUSION}

Compared to CON samples, sensory parameters (overall scores, external aspect, and muscle elasticity) were improved, values of ultimate $\mathrm{pH}, \mathrm{TVN}, \mathrm{TBA}$, peroxide, and NEFA were decreased, and bacterial contamination was reduced in muscle samples of MOLE supplemented broilers over storage time compared to CON. Based on previous findings, $M$. oleifera as natural feed supplement improved the quality and prolonged the stability and shelf-life of the breast meat from broilers stored under chilling condition.

\section{ACKNOWLEDGMENTS}

The authors express their gratitude to Dr. agr. Elke Albrecht, at Leibniz Institute for Farm Animal Biology (FBN), Dummerstorf, Germany, for her excellent assistance. Also the authors would like to thank Taif University for funding this study.

\section{CONFLICT OF INTEREST}

The authors declare that there is no conflict of interest.

\section{AUTHORS' CONTRIBUTION}

All authors listed have made a substantial, direct, and intellectual contribution to the work, and approved it for publication.

\section{FUNDING}

The current work was funded by Taif University Researchers Supporting Project number (TURSP - 2020/57), Taif university, Taif, Saudi Arabia.

\section{DATA AVAILABILITY}

The datasets generated during and/or analysed during the current study are available from the corresponding author on reasonable request.

\section{ETHICS STATEMENT}

This research was performed in the wake of the animal ethics rules of the Faculty of Veterinary Medicine, University of Sadat City.

\section{REFERENCES}

1. Lipinski K, Antoszkiewicz Z, Kotlarczyk S, MazurKusnirek M, Kaliniewicz J, Makowski Z. The effect of herbal feed additive on the growth performance, carcass characteristics and meat quality of broiler chickens fed low-energy diets. Arch Anim Breed. 2019;62:33-40. doi: 10.5194/aab-62-33-2019

2. Gopi M, Dutta N, Pattanaik AK, et al. Effect of polyphenol extract on performance, serum biochemistry, skin pigmentation and carcass characteristics in broiler chickens fed with different cereal sources under hothumid conditions. Saudi J Biol Sci. 2020;27(10):27192726. doi: 10.1016/j.sjbs.2020.06.021

3. Alaklabi A. Genetic diversity of Moringa peregrina species in Saudi Arabia with ITS sequences. Saudi J Biol Sci. 2015;22(2):186-190. doi: 10.1016/j. 


\section{sjbs.2014.09.015}

4. Qwele K. Antioxidant activity and the quality of meat from goats and broilers supplemented with Moringa (Moringa oleifera) leaf. Master thesis, Faculty of Science and Agriculture. University of Fort Hare. 2011.

5. Moyo B, Oyedemi S, Masika PJ, Muchenje V. Polyphenolic content and antioxidant properties of Moringa oleifera leaf meal extracts and enzymatic activity of liver from goats supplemented with Moringa oleifera/Sunflower seed cake. Meat Sci. 2012;91:441447. doi: 10.1016/j.meatsci.2012.02.029

6. Meireles D, Gomes J, Lopes L, Hinzmann M, Machado J. A review of properties, nutritional and pharmaceutical applications of Moringa oleifera: integrative approach on conventional and traditional Asian medicine. Adv Tradit Med. 2020;20:495-515. doi: 10.1007/s13596020-00468-0

7. Su B, Chen X. Current status and potential of Moringa oleifera leaf as an alternative protein source for animal feeds. Front Vet Sci. 2020;7:53. doi: 10.3389/ fvets.2020.00053

8. Wapi C, Nkukwana TT, Hoffman LC, et al. Physicochemical shelf-life indicators of meat from broilers given Moringa oleifera leaf meal. S Afr J Anim Sci. 2013;43:43-47. doi: 10.4314/sajas.v43i5.8

9. Nkukwana TT, Muchenje V, Masika PJ, Hoffman LC, Dzama K. The effect of Moringa oleifera leaf meal supplementation on tibia strength, morphology, and inorganic content of broiler chickens. S Afr J Anim Sci. 2014;44(3):228-239. doi: 10.4314/sajas.v44i3.4

10. Obaroh IO, Keta JN, Nwaogu J, Abdullahi A. Effects of Moringa oleifera Saponins Extract on Histology of Liver and Intestine of Clarias gariepinus. Asian J Biol Sci. 2020; 13:335-340. doi: 10.3923/ajbs.2020.335.340

11. Brogna DM, Nasri S, Salem HB, et al. Effect of dietary saponins from Quilaja saponaria L. on fatty acid composition and cholesterol content in muscle Longissimus dorsi of lambs. Animal. 2011;5(7):11241130. doi: $10.1017 /$ S1751731111000048

12. Mahfuz S, Piao XS. Application of Moringa (Moringa oleifera) as Natural Feed Supplement in Poultry Diets. Animals. 2019;9:431. doi: 10.3390/ani9070431

13. Mir NA, Rafiq A, Kumar F, Singh V, Shukla V. Determinants of broiler chicken meat quality and factors affecting them: a review. J Food Sci Technol. 2017;54(10): 2997-3009. doi: 10.1007/s13197-0172789-z

14. Walley K, Parrot P, Custance P, Meledo-Abrahim P, Bourdin A. A review of French consumers purchasing patterns, perceptions, and decision factors for poultry meat. Worlds Poult Sci J. 2015;71: 5-14. doi: 10.1017/ S004393391500001X

15. Abd El-Hack ME, Alagawany M, Elrys AS, et al. Effect of Forage Moringa oleifera L. (moringa) on Animal Health and Nutrition and Its Beneficial Applications in Soil, Plants and Water Purification. Agriculture. 2018;8:145. doi: 10.3390/agriculture8090145

16. Moyo B, Masika PJ, Hugo A, Muchenje V. Nutritional characterization of Moringa (Moringa oleifera Lam.) leaves. Afr J Biotechnol. 2011;10:12925-12933. doi: 10.5897/AJB10.1599

17. Lourenco SC, Moldao-Martins M, Alves VD. Antioxidants of Natural Plant Origins: From Sources to Food Industry Applications. Molecules. 2019;24(22): 4132. doi: 10.3390/molecules 24224132

18. Jung S, Choe J, Kim B, Yun H, Kruk, ZA, Jo C. Effect of dietary mixture of garlic acid and linoleic acid on antioxidative potential and quality of breast meat from broilers. Meat Sci. 2010;86:520-526. doi: 10.1016/j. meatsci.2010.06.007

19. Leygonie C, Britz TJ, Hoffman LC. Impact of freezing and thawing on the quality of meat: A review. Meat Sci. 2012;91(2):93-98. doi: 10.1016/j.meatsci.2012.01.013

20. Manessis G, Kalogianni Al, Lazou T, Moschovas M, Bossis I, Gelasakis Al. Plant-Derived Natural Antioxidants in Meat and Meat Products. Antioxidants 2020;9:1215. doi: 10.3390/antiox9121215

21. Qwele K, Muchenje V, Oyedemi SO, Moyo B, Masika PJ. Effect of dietary mixtures of moringa (Moringa oleifera) leaf, broiler finisher and crushed maize on anti-oxidative potential and physico-chemical characteristics of breast meat from broilers. Afr J Biotechnol. 2013;12(3):290-298. doi: 10.5897/ AJB12.115

22. Nfambi J, Bbosa GS, Sembajwe LF, Gakunga J, Kasolo $\mathrm{JN}$. Immunomodulatory activity of methanolic leaf extract of Moringa oleifera in Wistar albino rats. JBCPP. 2015;26:603-11. doi: 10.1515/jbcpp-2014-0104

23. World's Poultry Science Association, World's Poultry Science Association Working Group No. 5. Recommendations for a standardized method of sensory analysis for broilers. World's Poult. Sci. J. 1987; 43: 64-68.

24. International Organization for standardization ISO. Sensory Analysis - General Guidance for the Design of Test Rooms. ISO 8589 1988:1-9. https://www.iso.org/ standard/15879.html

25. Horwitz, William. Official Methods of Analysis of AOAC International. Gaithersburg, Md: AOAC International, 2000.http://www.worldcat.org/oclc/44761301.

26. Conway EJ, Byrne A. An absorption apparatus for the micro-determination of certain volatile substances: The micro-determination of ammonia. Biochem J. 1933;27(2):419-429. PMCID: PMC1252897. PMID: 16745115

27. Pikul J, Leszezynski DE, Kummerow F. Evaluation of three modified TBA methods for measuring lipid oxidation in chicken meat. J Agric Food Chem. 1989;37:1309-1313. doi: 10.1021/jf00089a022

28. Asakawa T, Matsushita S. Colorimetric determination of peroxide value with potassium iodide-silica gel reagent. J Am Oil Chem Soc. 1978;55:619-620. doi: 10.1007/BF02678958

29. Folch J, Lees M, Sloane SG. A simple method for the isolation and purification of total lipids from animal tissues. J Biol Chem. 1957;226(1):497-509. PMID: 13428781. doi: 10.1016/S0021-9258(18)64849-5

30. Brake NC, Fennema OR. Lipolysis and lipid oxidation in frozen minced mackerel as related to molecular diffusion and presence of gelatin. Journal of food science. 1999;64(1):25-32.

31. Ke PJ, Woyewoda AD. A titrimetric method for determination of free fatty acids in tissues and lipids with ternary solvents and $\mathrm{m}$-cresol purple indicator. 
Analytica Chimica Acta. 1978;99(2):387-391. doi: 10.1016/S0003-2670(01)83585-6

32. Hassan AHA, Zeinhom MMA, Abdel-Wahab, MA, Tolba $\mathrm{MH}$. Heavy Metal Dietary Intake and Potential Health Risks for University Hostel Students. Biol Trace Elem Res. 2016;170(1):65-74. doi: 10.1007/s12011-0150451-z

33. ICMSF. Microorganisms in Foods 5. Characteristics of Microbial Pathogens, Blackie Academic \& Professional, London. 1996 (ISBN 041247350 X). Available from Springer at http://www.springeronline.com

34. International Organization for standardization ISO. Microbiology of food and animal feeding stuffs - Horizontal methods for the detection and enumeration of Enterobacteriaceae - Part 2: Colonycount method. ISO 21528-2:2004. https://www.iso. org/standard/34566.html.

35. Harvey RW, Price TH. Comparison of Selenite F, Muller Kauffmann Tetrathionate and Rappaport medium for Salmonella isolation from chicken giblets after pre-enrichment in buffered peptone water. Journal of Hygiene. 1981;87:219-224. doi: 10.1017/ S0022172400069436

36. Cruickshank R, Duguid JP, Marmion BP, Swain RHA. Medical Microbiology, 12th Edition, Edward Arnold Publishers. Vol. II. 1975.

37. Krieg NR, Holt JG. Bergey's Manual of Systematic Bacteriology, vol. 1, Williams \& Wilkins Co., Baltimore, USA, 1984; 161-172.

38. Kok T, Worswich D, Gowans E. Some Serological Techniques for Microbial and Viral Infections. In: Mackie and Mccartney Practical Medical Microbiology, Collee, J., A. Fraser, B. Marmion and A. Simmons (Eds.). 14th Edn., Elsevier, India, ISBN: 9788131203934, 1996; pp: 179-204.

39. Andrews W, Wang H, Jacobson A, Hammack, T Cap. 5 Salmonella Bacteriological Analytical Manual (BAM), FDA 2016, consultado 08/11/2016, disponible en:http://www.fda.gov/Food/FoodScienceResearch/ LaboratoryMethods/ucm2006949.htm

40. Kauffmann G. Kauffmann white scheme. WHO-BD/72, 1.Rev. 1. Acta Path Microbiol Scand. 1974;61:385-7. https://doi.org/10.1016/j.bjbas.2015.11.010

41. Lancette GA, Tatini SR. Staphylococcus aureus. In Compendium of Methods for the Microbiological Examination of Foods, C. Vanderzant and D. F. Splittstoesser, Eds., pp. 533-550, American Public Health Association, Washington, DC, USA, 3rd edition, 1992. doi: $10.1155 / 2016 / 9041636$

42. Muchenje V, Dzama K, Chimonyo M, Strydom PE, Hugo A, Raats JG. Sensory evaluation, and its relationship to quality attributes of beef from Nguni and Bonsmara steers raised on natural pasture. Animal. 2008;2:17001706. doi: $10.1017 /$ S1751731108002802

43. Muchenje V, Dzama K, Chimonyo M, Strydom PE, Hugo A, Raats JG. Some biochemical aspects pertaining to beef eating quality and consumer health : A review. Food Chem. 2009;112:279-289. doi: 10.1016/j. foodchem.2008.05.103

44. Modisaojang-Mojanaga MM, Ogbuewu IP, Oguttu JW, Mbajiorgu CA. Moringa leaf meal improves haematobiochemical and production indices in broiler chickens: a review. Comp Clin Path. 2019;28:621-632. doi: 10.1007/s00580-019-02900-7

45. Cui Y, Wang J, Lu W, Zhang H, Wu S, Qi G. Effect of dietary supplementation with Moringa oleifera leaf on performance, meat quality, and oxidative stability of meat in broilers. Poult Sci. 2018;97(8):2836-2844. doi: $10.3382 /$ ps/pey122

46. Karthivashan G, Arulselvan P, Alimon A, Ismail IS, Fakurazi S. Competing Role of Bioactive Constituents in Moringa oleifera Extract and Conventional Nutrition Feed on the Performance of Cobb 500 Broilers. BioMed Res Int. 2015;2015:970398. doi: 10.1155/2015/970398

47. Qwele K, Hugo A, Oyedemi SO, Moyo B, Masika PJ, Muchenje V. Chemical composition, fatty acid content and antioxidant potential of meat from goats supplemented with Moringa (Moringa oleifera) leaf, sunflower cake and grass hay. Meat Sci. 2013;93:455462. doi: 10.1016/j.meatsci.2012.11.009

48. Tiwari AK, Madhusudana RJ. Diabetes mellitus and multiple therapeutic approaches of Phytochemicals: present status and future prospects. Curr Sci. 2002;83:30-38.

49. Tende JA, Ezekiel I, Dikko AAU, Goji ADT. Effect of Ethanolic Leaf Extract of Moringa oleifera on Blood Glucose Levels of Streptozocin-Induced Diabetics and Normoglycemic Wistar Rats. Br J Pharmacol. 2011;3:14.

50. Ezeonwu VU. Effects of bi-herbal ethanolic extract of phyllanthus niruri and moringa oleifera on the plasma glucose level and hematological parameters of streptozocin-induced diabetic albino rats. Journal of Medical and Applied Biosciences. 2012;4:26-31.

51. Asadi-Shekaari M, Kalantaripour TP, Nejad FA, Namazian $E$, Eslami A. The anticonvulsant and neuroprotective effects of walnuts on the neurons of rat brain cortex. Avicenna J Med Biotechnol. 2012;4(3):155-158. PMID:23407239; PMCID:PMC3558213.

52. Abd-Eldaim MA, Shaban A, Abd-Elaziz SA. Moringa oleifera Leaf Aqueous Extract Ameliorates Hepatotoxicity in Alloxan Induced Diabetic Rats. Biochem Cell Biol. 2017;95(4):524-530. doi: 10.1139/ bcb-2016-0256

53. Yadav UC, Moorthy K, Baquer NZ. Effects of sodiumorthovanadate and Trigonella foenum-graecum seeds on hepatic and renal lipogenic enzymes and lipid profile during alloxan diabetes. J Biosci. 2004;29(1):8191. doi: 10.1007/BF02702565

54. Anwar F, Latif S, Ashraf M, Gilani AH. Moringa oleifera: a food plant with multiple medicinal uses. Phytother Res. 2007;21:17-25. doi: 10.1002/ptr.2023

55. Al-Farsi MA, Lee CY. Optimization of phenolics and dietary fiber extraction from date seeds. Food Chem. 2008;108(3):977-985. doi: 10.1016/j. foodchem.2007.12.009

56. Bijina B, Chellappan S, Krishna JG, et al. Protease inhibitor from Moringa oleifera with potential for use as therapeutic drug and as seafood preservative. Saudi J Biol Sci. 2011;18(3):273-281. doi: 10.1016/j. sjbs.2011.04.002

57. Shahid M, Pourrut B, Dumat C, Nadeem M, Aslam $M$, Pinelli $E$. Heavy-metal-induced reactive oxygen species: phytotoxicity and physicochemical changes 
in plants. Rev Environ Contam Toxicol. 2014;232:1-44. doi: 10.1007/978-3-319-06746-9_1

58. Donkor AM, Glover RLK, Addae D, Kubi KA. Estimating the nutritional value of the leaf of Moringa oleifera on poultry. Food Sci Nutr. 2013;4(11):1077-1083. doi: 10.4236/fns.2013.411140

59. Khan Z, Sultan A, Khan R, Khan S, Imranullah, Kamran F. Concentrations of heavy metals and minerals in poultry eggs and meat produced in Khyber Pakhtunkhwa,
Pakistan. Meat Sci Vet Public Health. 2016;1(1):4-10.

60. Amabye TG, Tadesse FM. Phytochemical and Antibacterial Activity of Moringa Oleifera Available in the Market of Mekelle. J anal pharm Res. 2016;2(1):00011. doi: 10.15406/japlr.2015.02.00011

61. Adamu YA, Shamsudeen S. Effect of moringa oleifera leaf meal as a substitute for antibiotics on the performance and blood parameters of broiler chicken in Sokoto, Nigeria. Int educ res J. 2015;1(3):21-23. 